pregledni

naučni

članak

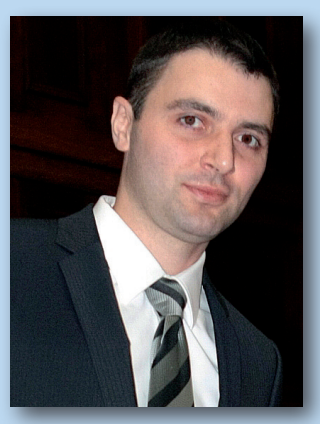

mr Vladimir Marinković

Sunce Marinković doo vladimirm@suncemarinkovic.com 


\section{THE IMPORTANCE OF IMPLEMENTING CRM CONCEPT IN THE BANKING SECTOR}

\section{Summary}

In the past banks traditionally operated at the predominantly stable market. With the outbreak of the economic crisis and the increased number of competitors the situation has drastically changed. Today banks are facing aggressive competition, which requires additional efforts in order to ensure survival at the competitive and unpredictable market. Customers are the essence and basis of the banking sector's development. Banks cannot function without customers. This is why Customer Relationship Management (CRM) is of strategic importance for the banking sector. CRM helps banks to achieve profit by establishing long-term relations.

High-quality customer relationship management is only possible with the support of a sound IT system. The practice among companies has shown that investments in the CRM system and customer relations are usually intuitive and based on the management's experience, with no detailed investment plan as in the case of other investment fields. Banks have realized that customer relationship management is an extremely significant factor of their success. CRM is a strategy that may help them build long-term relations with their clients, thereby increasing their profit through an adequate management system and implementation of customer-oriented strategy.

Keywords: CRM, customer relationship, client satisfaction, client management

JEL: G21, M31

Paper received: 08.10.2014

Approved for publishing: 20.01.2015 


\section{Pojam CRM-a}

Upravljanje odnosima sa potrošačima (CRM - Customer Relationship Management) predstavlja relativno mlad koncept, koji u savremenoj tržišnoj privredi, paralelno sa razvojem informacionih tehnologija (uključujući i softver za kreiranje baza podataka), označava dvosmernu komunikaciju kompanije i potrošača kao prioritet poslovnih aktivnosti. CRM predstavlja neizostavan deo poslovnih aktivnosti svih finansijskih institucija. CRM se može definisati kao poslovna filozofija koja se odnosi na upravljanje odnosima sa kupcima i usmeravanje kompanije na zadržavanje i razvoj postojećih kupaca.

Otkad je koncept relacionog marketinga predstavljen od strane Berry-ja (Berry, 1983, str. 25), redefinisan od strane Gummesson-a (Gummesson, 1994, str. 5-20), CRM je postao jedan od dominantnijih marketinških pristupa. Postavljajući kupca u središte, CRM se temelji na integrisanom upravljanju tržištem, prodaji i pružanju usluga za klijente, kao ključnim funkcijama banaka koje se svakodnevno susreću sa kupcima. CRM predstavlja strateški pristup u izgradnji vrednosti za stejkholdere, kroz razvoj odnosa sa potrošačima (Knox i ostali, 2003, str. 268-269).

Bankama, kao i svim drugim učesnicima na tržištu, na raspolaganju stoje uvek dve strategije: agresivno pridobijanje novih kupaca, ili defanzivno ulaganje napora u zadržavanje postojećih (Kotler i Bliemel, 1995). U prvom slučaju, banka je usmerena na što veći broj "transakcija" (ostvarenih prodaja), što je tipično za tržišta na kojima je tražnja veća od ponude. Agresivan nastup podrazumeva pridobijanje novih kupaca i ohrabrivanje korisnika koji već koriste usluge konkurentskih banaka da promene dobavljača usluga. Na drugoj strani, defanzivna strategija je usmerena na odbranu postojećeg tržišnog udela i zaštitu baze potrošača, odnosno na zadržavanje postojećih korisnika i generisanje buduće poslovne strategije, koja proizilazi iz toga.

$\mathrm{U}$ poređenju sa relacionim marketingom, CRM intenzivnije analizira problem dugoročnih odnosa sa potrošačima, polazeći od svih elemenata i to od uspostavljanja organizacione strukture i ostalih pretpostavki razvoja (poslovna kultura i sl.) do samih programa uspostavljanja razvoja dugoročnih odnosa, dok je kod marketinških odnosa veći akcenat na finalizaciji i konkretnim programima uspostavljanja dugoročnih odnosa, kao što su komunikacija, prilagođavanje ponude, program lojalnosti i sl. (Domazet, 2007, str. 2-9).

Za Kellogg-ovu školu, CRM predstavlja dodirnu tačku između kupca i kompanije, kao set interakcije sa kupcem, bez obzira na to ko ga inicira, nastojeći da interakcija bude specifična i prilagođena. Prema Kellogg-ovim autorima, među kojima je i Kotler, CRM bi trebalo da se bavi individualnošću pojedinačnih kupaca. Kao takav, CRM predstavlja strateški alat i konkurentsku prednost za kompanije. Osnovni ciljevi CRM-a su optimizacija upravljanja životnim ciklusom klijenata, povećanje profitabilnosti i postizanje najvišeg stepena lojalnosti kupca. Mnoge empirijske studije su potvrdile neophodnost kontinuiranog unapređenja CRM strategije i osnaživanja kvaliteta veza i dugoročne lojalnosti brendu. Ako je CRM program za banke dobro kreiran i primenjen, to će ojačati lojalnost korisnika. Ako nije, imaće suprotne efekte.

Ističe se interaktivnost CRM-a, prema kojoj je CRM proces koji predstavlja optimalnu ravnotežu između investicija kompanije i zadovoljenja potreba potrošača, a koji sadrži (Shaw i Reed, 1999):

- merenje svih ulaznih i izlaznih komponenti - od troškova marketinga, prodaje i servisa do profita i vrednosti kapitala;

- pribavljanje i konstantno ažuriranje informacija o potrebama kupaca, njihovom ponašanju i motivaciji tokom celokupnog trajanja „odnosa“ kompanija-korisnik;

- učenje kroz pozitivna i negativna iskustva sa korisnicima;

- integrisanje funkcija marketinga, prodaje i servisa, kako bi se ostvario zajednički cilj;

- implementaciju odgovarajućih sistema za pribavljanje i zajedničko korišćenje informacija o kupcima, kao i merenje efikasnosti CRM podrške;

- stalno prilagođavanje balansa između funkcija marketinga, prodaje i servisa, u odnosu na promene potreba potrošača, sa ciljem da se maksimizira profit.

Upravljanje odnosima s kupcima daje očekivane rezultate samo ako je potpuno 


\section{The concept of CRM}

Customer Relationship Management CRM is a relatively young concept, which in the contemporary market economy, alongside the information technologies development (including the database generation software), refers to the two-way communication between a company and its customers, as its business priority. CRM is an inevitable segment of business activities of all financial institutions. CRM can be defined as a business philosophy referring to customer relationship management, and a company's orientation towards keeping and upgrading the existing customers.

Ever since the concept of relationship marketing was introduced by Berry (1983, p. 25), and redefined by Gummesson (1994, pp. 5-20), CRM has been one of the most dominant marketing principles. Focusing on the customer, CRM is based on integrated market management, sales and provision of services to the clients, as the key banking functions which deal with customers on a daily basis. CRM is a strategic approach with a view to generating value for stakeholders, by developing relationship with the customers (Knox et al, 2003, pp. 268-269).

Banks, like all other market participants, always have two available strategies: aggressive approach with a view to attracting new customers, or defensive investment of effort to keep the existing ones (Kotler and Bliemel, 1995). In the former case, banks are aiming for as many "transactions" (closed sales) as possible, which is typical for markets with higher demand than supply. Aggressive approach implies attracting new customers and encouraging the customers already using the services of competitive banks to change their service provider. On the other hand, defensive strategy is targeted at defending the existing market share and protecting the customer database, i.e. keeping the existing customers and generating a future business strategy arising thereof.

Compared to relationship marketing, CRM analyzes the problem of long-term customer relations more intensively, starting from the overall elements, establishing the organizational structure and other preconditions of development (business culture, etc.), to the very programs for long-term relations establishment. As opposed to that, marketing relationships put bigger emphasis on the finalization and concrete programs for long-term relations establishment, such as communication, offer adjustment, loyalty program, etc. (Domazet, 2007, pp. 2-9).

For Kellogg's school, CRM is a common ground between a customer and the company, as a set of interactions with the customer, regardless of who initiated it, with the tendency to make every interaction specific and tailormade. According to Kellogg's authors, including Kotler, CRM should be dealing with the individuality of each customer. As such, CRM is a strategic tool providing competitive edge to companies. The basic goals of CRM include the optimization of customer lifecycle management, increase of profitability and achievement of the highest level of customers' loyalty. Many empirical studies have confirmed the necessity of continuous upgrading of the CRM strategy, along with the strengthening of customer relationship quality and long-term loyalty to the brand. If the CRM program for banks is well-designed and duly implemented, it will strengthen customers' loyalty. Otherwise, it will yield the opposite effects.

What has been repeatedly underlined is interactivity of CRM, according to which CRM is a process establishing the optimum balance between a company's investments and the satisfaction of its customers' needs, and comprising the following aspects (Shaw and Reed, 1999):

- Measurement of all ingoing and outgoing components - from marketing, sales and servicing costs to profit and capital value;

- Procurement and constant updating of information about the customers' needs, their behavior and motivation throughout the entire company-customer "relationship";

- Learning through positive and negative experiences with the customers;

- Integration of the functions of marketing, sales and servicing, in order to achieve the common goal;

- Implementation of appropriate systems for procurement and joint usage of information about customers, along with the assessment of CRM support efficiency; 
integrisano $\mathrm{u}$ poslovanje banke i podržano dobrim informacionim sistemom. Prilikom definisanja CRM-koncepta, polaznu tačku predstavlja činjenica da se novi koncept odnosa sa potrošačima zasniva na novoj postavci marketing miksa - 4C, koji u stvari objašnjava kako potrošači gledaju na $4 \mathrm{P}$ (proizvod, cena, promocija i distribucija). Dok se formulacija $4 \mathrm{P}$ odnosi na akronim engleskih reči za elemente marketing miksa, instrumenti koncepta $4 \mathrm{C}$ su:

- Customer value - vrednost za kupca,

- Cost to the Customer - trošak,

- Convenience - pogodnost za kupca,

- Communication - komunikacija između prodavca i kupca

CRM koncept se može posmatrati kao integrisani skup aktivnosti koji unapređuje poslovanje banke kroz:

- identifikaciju, razumevanje i uspešno obraćanje korisnicima,

- ciljanu prodaju postojećih proizvoda i usluga novim i postojećim korisnicima,

- razvoj novih atraktivnih ponuda, cenovnih popusta i marketinških programa namenjenih klijentima i

- podelu dobiti sa najprofitabilnijim klijentima, jer zadovoljan korisnik postaje lojalan korisnik.

\section{Ciljevi CRM-a}

CRM karakteriše upravljačka filozofija koja za cilj ima izgradnju dugoročnih i profitabilnih odnosa sa kupcima (Raab i Werner, 2009). Dugoročno znači da banka zadobije konstantno poverenje potrošača, koje će omogućiti njegovu doživotnu vezanost za proizvode i usluge iste. Pri tome se ističe važnost izgradnje odnosa, u smislu orijentacije banke ka kupcu, a ne ka proizvodu/usluzi. Trajnost ovakvih odnosa osigurava ostvarenja profita na duži rok.

Cilj koji banke žele da ostvare je da utiču na potencijalne korisnike da više koriste njihove usluge, da se pretplate, da se registruju, odgovaraju na upite i ankete, da generišu preporuke, čime u krajnjoj instanci utiču na konkurentsku poziciju banke. Potencijalni korisnici, kao i banka, imaju svoje ciljeve zadovoljenje potreba i razumevanje, kao i strategije za postizanje planiranog. Proces $\mathrm{u}$ kome potencijalni korisnik postaje i ostaje stvarni potrošač, koji svojom lojalnošću unapređuje poslovanje preduzeća utemeljen je na proverenim principima koji uključuju analitiku, umetnost komunikacije, CRM koncept i fundamentalna ekonomska znanja.

Fundamentalni cilj CRM-a je da osigura čvrst pravac ostvarenja profita i maksimiziranje vrednosti kupca, i ponašanje kupaca koje osnažuje prihod i profit čime postaje suštinski značajan. Pored toga, cilj CRM-a je da postigne efektivnije (i efikasnije) ostvarivanje ciljeva banke, detaljnijim i analitičnijim sagledavanjem stvarnih potreba potrošača. Jedan od ciljeva je i stvaranje vrednosti - u procesu identifikacije, privlačenja i održavanja dugoročnih odnosa sa potrošačima - koja nastaje kao rezultat interakcije banke i korisnika, što dalje omogućava stvaranje profitabilnih odnosa sa klijentima. Kao što omogućava prednosti za banku, CRM bi trebalo da obezbedi i vrednost za kupca (Shaw i Reed, 1999) i vrednost za kompaniju (Helm i Günter, 2003), koja nastaje kroz povećanje vrednosti kupca, i pozitivno se odražava na rezultat kompanije. Vrednost kupca (Customer Equity) se definiše kao neto korist poslovnog odnosa iz perspektive ponuđača, dok sama korist za kupca (Customer Value) predstavlja neto korist iz perspektive potrošača. Vrednost kupca i korist kupca čine dva osnovna cilja u konceptu CRM-a.

Kreiranjem i razvojem dugoročnih odnosa sa kupcima, generiše se vrednost, kojom CRM koncept stvara konkurentsku prednost za banku (i za korisnike). Ovo je razlog zbog čega se CRM pozicionira visoko na listi prioriteta današnje korporativne agende i usko je povezan sa korišćenjem informacionih tehnologija, neophodnih za implementaciju marketinških strategija odnosa sa kupcima.

\section{CRM kao proces}

Na efikasnost i uspeh CRM-a u uslužnim delatnostima, među kojima se nalaze i odnosi banka-korisnik, najvažniju ulogu igraju proaktivnost, posvećenost kupcu, umerenost (skromnost), lični odnos, briga o korisniku, etičnost kompanije, preporuke drugih korisnika (promocija preko preporuka) i orijentisanost na tehnologiju (Jain i ostali, 2007).

Tri su osnovna procesa u upravljanju odnosima sa potrošačima (Österle, 1995): 
- Permanent adjustment of the balance between the functions of marketing, sales and servicing based on the changes in customers' needs, with a view to maximizing profit.

Customer relationship management yields expected results only if it is fully integrated into the bank's business and is supported by a sound IT system. The starting point in the process of defining the CRM concept is the fact that the new concept of customer relationship is based on a new angle on the $4 \mathrm{C}$ marketing mix, which actually explains how customers perceive the $4 \mathrm{P}$ (product, price, promotion and placement). While the 4P formulation is an acronym made of the English words denoting the marketing mix elements, the instruments of the $4 \mathrm{C}$ concept are:

- Customer value;

- Cost to the Customer;

- Convenience;

- Communication.

CRM concept can be viewed as an integrated set of activities enhancing the bank's business by means of the following:

- Identification, consideration and successful approach to customers;

- Targeted sale of existing products and services to both new and existing customers;

- Development of new attractive offers, discounts and marketing programs tailored for the customers; and

- Sharing of benefits with the most profitable clients, because a satisfied client becomes a loyal client.

\section{Objectives of CRM}

CRM is characterized by a management philosophy aimed at establishing long-term and profitable relations with the customers (Raab and Werner, 2009). "Long-term" means that a bank earns the permanent confidence of consumers enabling their lifetime connection with that bank's products and services. The important aspect in that process is to build the relationship in terms of the bank's orientation towards the consumer, instead of towards a product/service. The permanence of such relations ensures the achievement of profit in the long run.

The objective every bank is striving for is to motivate potential consumers to use their services to a greater extent, to subscribe, to register, to respond to inquiries and questionnaires, to generate recommendations, thereby ultimately affecting the bank's competitive position. Potential customers, just like the bank, have objectives of their own satisfaction of their needs, appreciation and strategies for achieving the planned goals. The process in which a potential customer becomes and remains the actual consumer, thereby improving the company's business owing to his loyalty, is based on the wellestablished principles including analytics, art of communication, CRM concept and fundamental knowledge of economics.

The fundamental goal of CRM is to ensure a firm path towards achieving profit and maximizing customer equity, and such customer behavior that boosts income and profit, which is why this goal is essential. Moreover, the objective of CRM is to achieve a more effective (and efficient) realization of the bank's goals, through a more detailed and analytical consideration of actual needs of the consumers. Another objective is to generate value - in the process of identifying, attracting and maintaining long-term consumer relationships - which occurs as a result of the interaction between the bank and its consumers, in turn enabling the establishment of profitable relations with the clients. Just as it brings certain advantages to the bank, CRM should also generate customer value (Shaw and Reed, 1999) and customer equity (Helm and Günter, 2003), which is produced based on higher customer value, positively affecting the company's business results. Customer equity is defined as the net benefit of the business relationship from the offeror's perspective, whereas customer value represents the net benefit of the business relationship from the customer's perspective. Customer equity and customer value are two main objectives within the CRM concept.

The establishment and development of long-term relations with the customers generates value which adds some competitive advantage to the bank (and its customers). This is why CRM is highly positioned at the list of priorities of today's corporate agenda, and is closely related to the usage of information technologies, necessary for the implementation of CRM marketing strategies. 
- CRM upravljački procesi - procesi koji imaju upravljačku i kontrolnu funkciju nad ostalim procesima (razvoj strategije CRM-a, upravljanje procesima CRM-a.). Ovi procesi nemaju direktan kontakt sa kupcima, ali kontrolišu i upravljaju aktivnostima koje imaju veze sa njima.

- CRMuslužni procesi-procesikojiobuhvataju sve aktivnosti vezane za direktan kontakt sa kupcima (upravljanje kampanjama, prodajom, uslugama, reklamacijama).

- CRM procesi podrške - procesi koji omogućavaju upravljanje i analizu informacijama i podacima, koje su dobijene u uslužnim procesima. Rezultati analize omogućavaju poboljšanje efektivnosti izlaza koji nastaju iz uslužnih procesa (segmentacija kupaca, edukacija korisnika, izveštavanje). Ovi procesi, takođe, nemaju direktnog kontakta sa kupcima.

Efikasnost CRM procesa, koji treba da bude integrisan kroz marketing, prodaju i kroz odnos sa potrošačima, podrazumeva za banku:

- identifikaciju faktora koji doprinose uspešnom odnosu sa korisnicima

- razvoj prakse odnosa sa korisnicima,

- razvoj procesa koji će pogodovati korisnicima bankarskih proizvoda/usluga,

- formulisanje pitanja koja bi na najadekvatniji način pomogla rešenju potencijalnih problema korisnika,

- preporuku rešenja za korisnike koji imaju žalbu na proizvod/uslugu,

- praćenje prodaje, kao i podršku potrošačima. Ističu se dve ključne stvari na koje banke koje žele da implementiraju CRM sistem, treba da odgovore (Renart i Cabré, 2007):

1. Imamo li potencijal za ostvarivanje veza?

2. Da li korisnici žele da ostvaruju vezu sa našom kompanijom? Postoje korisnici koji žele da sarađuju sa kompanijom na čistoj transakcionoj osnovi.

Aktivnosti koje banka sprovodi na izgradnji odnosa daju suštinu njenoj CRM strategiji, isto kao što njeni proizvodi i usluge daju suštinu marketinške strategije. Banka počinje usmeravanje prema korisnicima definisanjem misije, vrednosti i kulture (slika 1). 


\section{CRM as a process}

What most affects the efficiency and success of CRM in the service industry, including bankcustomer relations, is proactivity, dedication to each customer, moderateness (modesty), personal approach, customer care, corporate ethics, recommendations by other consumers (recommendation-based promotion), and technology orientation (Jain et al, 2007).

There are three basic groups of processes within customer relationship management (Österle, 1995):

- CRM management processes - i.e. processes that have the function of management and control over other processes (CRM strategy development, CRM processes management). These processes are not directly related to consumers, but they control and manage activities related to them.

- CRM service processes - i.e. processes encompassing all activities related to direct contact with the consumers (managing campaigns, sales, services, complaints).

- CRM support processes - i.e. processes enabling management and analysis of information and data obtained from the service processes. The results of these analyses enable higher effectiveness of service process outputs (customer segmentation, client education, reporting). These processes do not imply any direct contact with consumers either.
The efficiency of the CRM process, which should be integrated through marketing, sales and customer relations, implies the following aspects for the bank:

- Identification of factors contributing to a successful customer relationship;

- Development of customer relationship practice;

- Development of the processes tailored for the users of banking products/services;

- Formulating issues that could most adequately help solving potential problems indicated by the customers;

- Recommended solution for customers complaining about certain product/service;

- Sales monitoring and customer support.

Two crucial things that banks wishing to implement a CRM system should address are the following (Renart and Cabré, 2007):

1. Do we have the potential required for establishing relations?

2. Do customers want to establish relations with our company? There are customers wishing to cooperate with the company on a purely transaction basis.

The activities conducted by the bank wishing to build relationships lie in the core of its CRM strategy, just like its products and services lie in the core of its marketing strategy. The bank starts its customer orientation by defining its mission, value and culture (Figure 1). 
Slika 1: CRM proces iz generalne perspektive menadžmenta (Renart i Cabré, 2007)

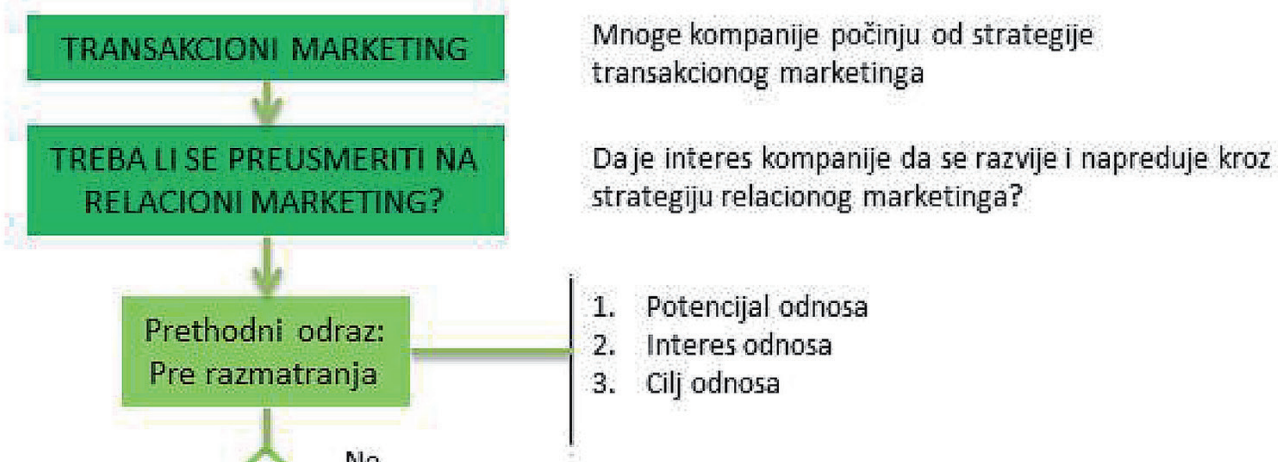

Odluka da se ne implementira strategija relacionog marketinga i da se nastavlja sa primenom transakcionog marketinga

Da

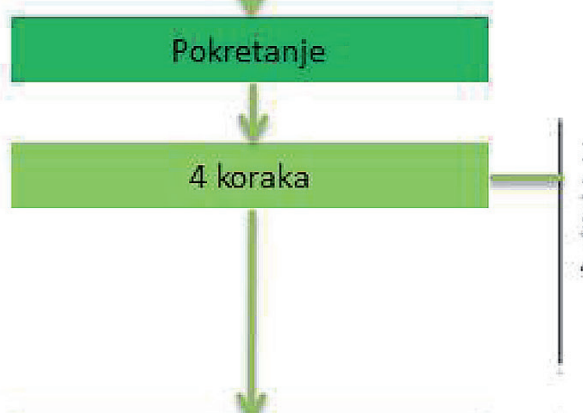

1. Definisanje misije, kulture i vrednosti

2. Kreiranje CRM strategije

3. Kreiranje i započinjanje CRM aktivnosti

4. Pribavljanje humanih i materijalnih resursa i menadžerskih kapaciteta

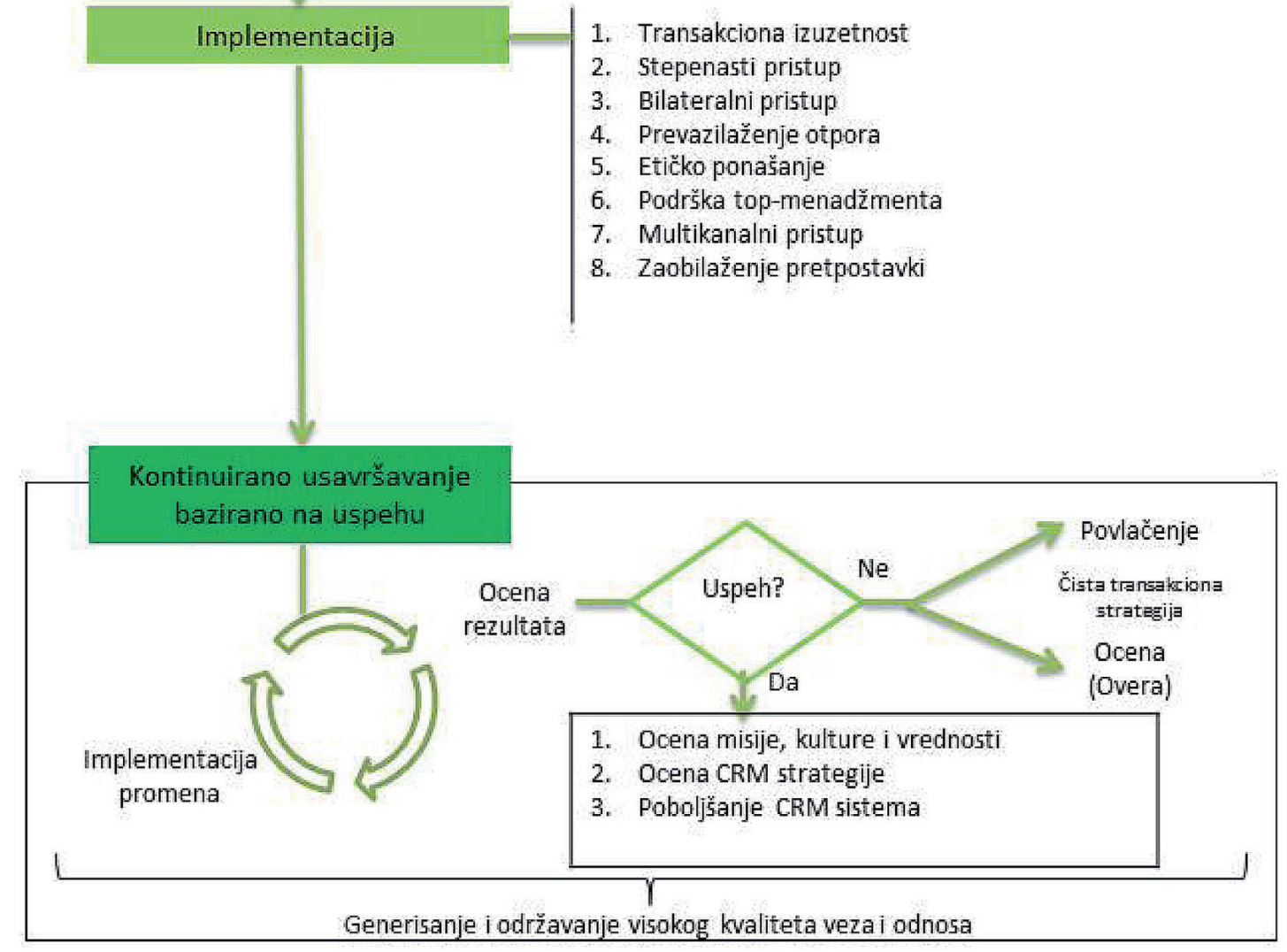

Banka bi, takođe, trebalo da identifikuje, izabere i implementira tehnologiju (CRM softver, veb sajt, intranet, ekstranet) i da pripremi ljudske resurse na upravljanje $\mathrm{i}$ sprovođenje CRM strategije.
Analizom CRM procesa, banka može razumeti korisnika i neće ponovo reagovati kada dođe do problema, već će proaktivno otkrivati skrivene mogućnosti za zadovoljenje sve većih zahteva korisnika. Ključni faktor 
Figure 1: CRM process from the general management's perspective (Renart and Cabré, 2007)

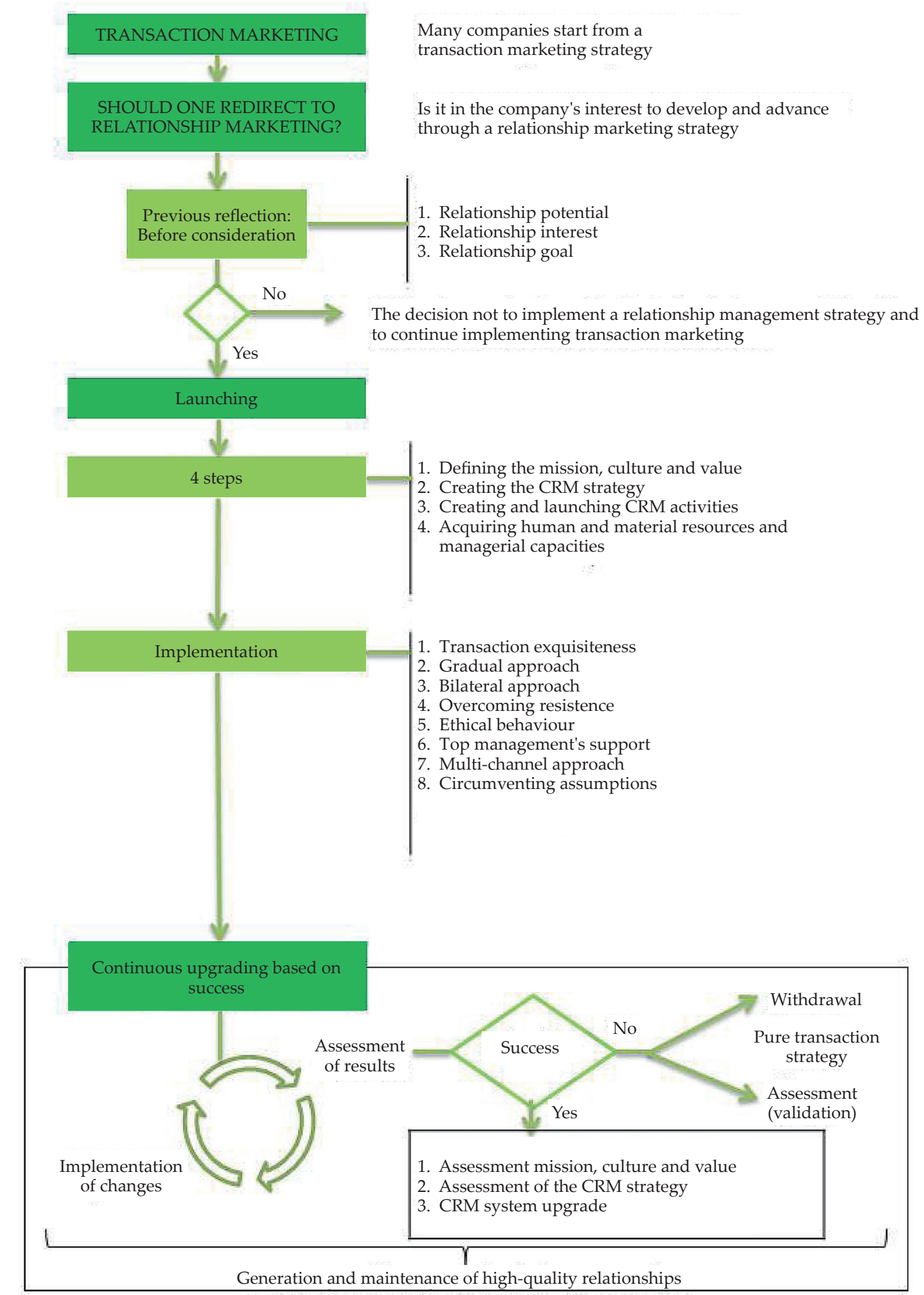

The bank should also identify, select and implement the relevant technology (CRM software, website, intranet, extranet), and prepare human resources to manage and implement the CRM strategy.
By conducting a CRM process analysis, the bank can understand its customers and will not find itself in the position to respond to a problem, instead proactively detecting the hidden possibilities for satisfying the 
uspeha CRM koncepta predstavljaju očekivanja korisnika, koja bi banke trebalo da anticipiraju. $\mathrm{U}$ tom cilju je neophodno napraviti platformu koja omogućava komunikaciju sa potrošačima, sakupljanje i analizu bitnih informacija koje se dobijaju od njih. Na ovaj način se može voditi evidencija o potrošačkim navikama i njihovim specijalnim interesovanjima.

CRM se okreće oko životnog ciklusa potrošača (slika 2). Banka počinje sa akvizicijom klijenata kroz kanale tradicionalnog marketinga, ili putem preporuke. Zatim ide u pravcu razvoja klijenata, kroz personalizaciju komunikacija i prilagođavanje proizvoda i usluga, kroz proces uzajamnog učenja. Zatim dolazimo do faze uticaja na vrednost potrošača putem procesa postprodaje, da bi se na kraju došlo do povraćaja ili zadržavanja klijenata i njihovih preporuka, u cilju stvaranja i pronalaženja novih korisnika. Kao rezultat razvoja ove teze, banke počinju da ističu vrednost kupca i samog klijenta, kao svoju najveću vrednost i imovinu kompanije.

Slika 2: Upravljanje životnim ciklusom potrošača

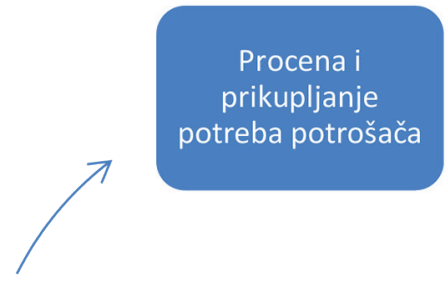

Zadržavanje

kupaca i preporuke

novim korisnicima
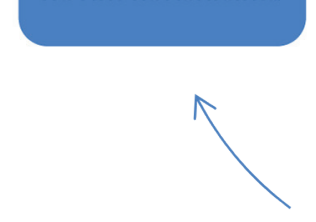

Stvaranje

vrednosti kupca

kroz Cross- i UpSelling.

tački dodira sa bankom. Ukoliko ovo može da postigne, IDIC methodologija bi trebalo da postigne tačne i profitabilne rezultate.

\section{CRM u bankarskom sektoru}

Kompanije kao Siebel, Epiphany, Oracle, Broadvision, Net Perceptions, Kana i druge su popunile CRM prostor proizvodima koji rade sve, od praćenja ponašanja kupca na internetu do predviđanja njegovih budućih aktivnosti i slanja direktnih mejlova. Ovo je kreiralo široko tržište za CRM proizvode i usluge koje je još 1999. vredelo 34 milijarde dolara, a 2004. 125 milijardi dolara (Wahab i ostali, 2010).

Još su Hedley i ostali (2006) primetili da će 2015. predstavljati godinu dramatičnih promena u bankarskoj industriji u radu sa stanovništvom, jer će korisnici postati individualniji, sa željom da kontrolišu svoj odnos sa bankom. Sa druge strane, za banke će ovo značiti zastarevanje i „izumiranje“ tradicionalnog pristupa segmentaciji korisnika.

Tradicionalno, CRM sistemi su okrenuti operativnom nivou funkcionisanja i orijentisani na prikupljanje što više podataka iz kupoprodajnog procesa i daljih transakcija i interakcija korisnika. Vrlo često oni ističu ciljeve banke i nisu uvek usmereni na potrebe korisnika. Imajući u vidu osnovnu svrhu uvođenja CRM sistema - da poveća promet i profit od lojalnih korisnika - mnoge banke doživljavaju ovaj sistem kao efikasan način da se poveća promet preko postojećih kupaca. Gartner Research navodi da je oko 46 milijardi dolara investirano $\mathrm{u}$ različite CRM sisteme, a da je 55\% svih CRM programa zapravo uticalo na smanjenje

Postoji, takođe, i IDIC metodologija koju je razvila konsultantska kuća Peppers $\mathcal{E}$ Rogers. Prema ovoj metodologiji kompanije preduzimaju četiri koraka u izgradnji odnosa sa klijentima: identifikovanje, diferencijacija, interakcija i prilagođavanje (Siddiqi i ostali, 2008). Ključna faza za primenu je metod koji omogućava identifikaciju korisnika na samoj broja korisnika, smanjenje prometa i profita i na udaljavanje od iskustva sa potrošačima (Karthikeyan, 2009).

Smanjenje troškova i povećanje efikasnosti sistema su osnovne prednosti koje nudi kvalitetan CRM za bankarske institucije. Pored toga, smanjuje se i kompleksnost i „zamršenost" koja nastaje usled proceduralnih 
increasing requirements of the clients. The key success factor of the CRM concept is customer expectations, which banks should be able to anticipate. To this end, it is necessary to create a platform enabling communication with the customers, and the subsequent collection and analysis of relevant information obtained from them. Thereby, records can be kept about customers' habits and their special interests.

CRM revolves around customer lifecycle (Figure 2). Banks start to acquire clients through traditional marketing channels or based on recommendations. Then, they strive towards client development, by personalizing communication and tailoring products and services, based on a mutual learning process. This is when they reach the stage of impacting customer value through post-sale processes, in order to, ultimately, retrieve or retain clients and their recommendations, with a view to attracting new customers. As a result of this thesis' development, banks start to highlight customer and client value as the company's biggest value and asset.

adjustment (Siddiqi et al, 2008). The stage crucial for implementation is the method enabling identification of customers at the very point of their connection with the bank. If it can achieve this, the IDIC methodology can achieve accurate and profitable results.

\section{CRM in the banking sector}

Companies like Siebel, Epiphany, Oracle, Broadvision, Net Perceptions, Kana, etc. populated the CRM field with all-in-one products, ranging from customer behavior monitoring on the Internet to anticipating their future activities, and sending direct e-mails. This has created a broad market for CRM products and services which was worth USD 34 billion back in 1999, and USD 125 billion in 2004 (Wahab et al, 2010).

Hedley et al (2006) were the first to notice that 2015 will be a year of dramatic changes in the retail banking industry, because the clients will become even more individualistic, with a desire to control their relationship with the bank. On the other hand,

Figure 2: Customer lifecycle management

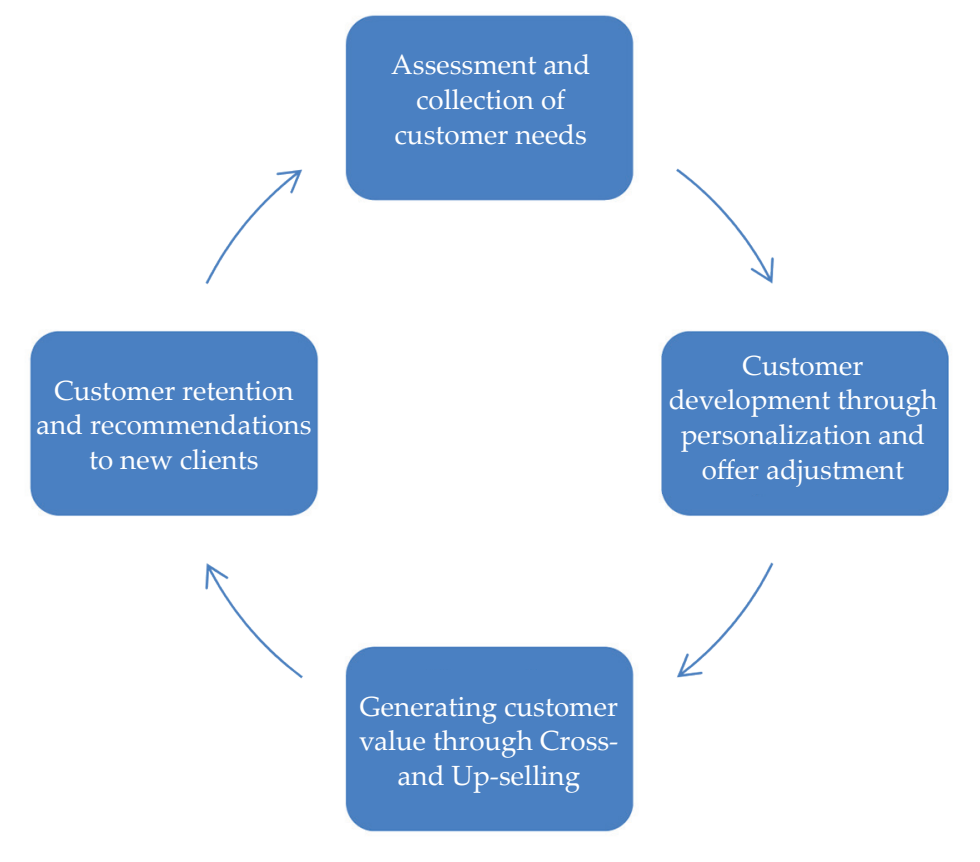
for banks this implies that the traditional approach to customer segmentation will become outdated and "extinct".

Traditionally, CRM systems are focused on operational level of functioning and oriented towards collecting as many data as possible from the process of sale/purchase, and subsequent customer transactions and interactions. Rather frequently, they highlight the bank's goals and are not always focused on customer needs. Bearing in mind the primary purpose of introducing a CRM system i.e. to boost turnover and profit from loyal customers - many banks perceive this system as

Furthermore, there is the so-called IDIC methodology developed by the consulting company Peppers \& Rogers. According to this methodology companies undertake four steps to develop their customer relations: identification, differentiation, interaction, and an efficient way to increase turnover based on the existing customers. Gartner Research states that about USD 46 billion has been invested in various CRM systems, and that $55 \%$ of all CRM programs actually caused a reduction of customers, lower turnovers and profits, as 
koraka, koji su često korisnicima nejasni i deluju zbunjujuće. Uvođenje CRM sistema u banke, povećava brzinu odziva na zahteve klijenata, što uzrokuje povećanje sposobnosti i kompetencija zaposlenih. Povećanje prometa i visok ROI (Return On Investment) se javljaju kao rezultat uvođenja CRM softverskog paketa (Stringfellow i ostali, 2004, str. 45-52). Na primeru grčke banke je pokazano da uvođenje CRM baze podataka omogućava uslugu $24 \mathrm{~h}$, 7 dana u nedelji, sa procentom uspešnosti od 92\%. (Blery i Michalakopoulos, 2006, str. 123). Na primeru ove banke vide se mnoge koristi od implementacije CRM-a: smanjenje troškova (jedan dobavljač sa dugotrajnim odnosom), pojednostavljenje (zajednička platforma za sve banke smanjila je potrebu za integracijom, pružila je jednu tačku kontakta i smanjila potrebu za tehničkom podrškom) i poboljšanja na operativnom nivou (povećane sposobnosti zaposlenih, smanjeni problem održavanja i podrške zbog jedinstvene platforme). Integracija "glasovnog bankarstva" u CRM-u je pomogla banci da se približi kupcima i ponudi telefonske bankarske usluge (transakcije na berzi, pozajmice itd). Uz to, banka nije morala da angažuje dodatnu radnu snagu, jer je novi Call-centar zadovoljavao povećani broj dolaznih poziva. Mnoge aktivnosti su bile prebačene iz filijala u kol-centar, pa su se tako operativni troškovi smanjili (trošak zaposlenog u Call-centru je upola niži od troška zaposlenog u filijali). Filijale su sada imale mogućnost da se bave specijalizovanim proizvodima i odnosima sa kupcima. Kao rezultat ove reorganizacije, banka je povećala broj svojih klijenata za 5\%, čime je potvrdila vrednost investicije.

Prema studiji koja je sprovedena u bankarskom sektoru u Švedskoj (Zineldin, 2005, str. 340), prednost lokacije, cene, preporuka od drugih i reklama nisu važni faktori izbora banaka. Iz perspektive klijenta, važni kriterijumi su: tačnost i pažljiv odnos prema računu i transakcijama, efikasnost $\mathrm{u}$ ispravljanju grešaka i prijateljski odnos $\mathrm{i}$ uslužnost zaposlenih u banci. Stoga, CRM atributi visokog kvaliteta proizvoda/usluge i diferencijacija se pokazuju kao najvažniji faktori za klijente. Druga studija sprovedena u Evropskoj banci (Blery i Michalakopoulos, 2006, str. 117) pokazuje da je sa CRM-om, banka bila u mogućnosti da se fokusira na profitabilne klijente, kroz efikasnu segmentaciju prema individualnom ponašanju. Informacije o tome ko kupuje, šta i koliko, omogućile su banci da ima komercijalan pristup baziran na klijentu, a ne samo na proizvodu. Zato je banka mogla da bolje zadovolji i zadrži svoje kupce. Investicija banke u novi telefonski bankarski sistem je smanjila troškove usluga, prebacivanjem nekih operacija iz predstavništava na novi Kolcentar, i prebacivanjem najmanje 70 zaposlenih sa drugih aktivnosti na prodaju, sa ciljem povećanja prihoda banke. Menadžer banke kaže: „CRM rešenje nam je dalo mogućnost da prebacimo preko 70 zaposlenih sa drugih poslova na prodaju, jačajući na taj način verovatnoću za dalje povećanje finansijskih pokazatelja banke". CRM rešenje je dalo banci viši stepen efektivnosti i performansi, i povećanje nivoa kvaliteta usluge i vremena odgovora. Vreme čekanja se smanjilo, sa oko 20 minuta na manje od 2 minuta, iako se obim telefonskih poziva povećao za oko $40 \%$. Uprkos povećanju obima usluga (bankarske transakcije, berzanske transakcije, zajmovi...), vreme razgovora se smanjilo za 50\%, zahvaljujući novom Kol-centru. Više od $75 \%$ telefonskih poziva obrade zaposleni na call-centru, a ostale IVR i glasovni sistem u banci. Banka je sada u mogućnosti da upravlja povećanim zahtevima mnogo efikasnije, bez potrebe da zapošljava dodatnih 7 ljudi, što bi bilo potrebno sa starim sistemom.

Takođe, CRM je podigao kapitalnu vrednost banke u smislu:

- koordinacije između operativnog i marketing sektora

- izgleda za nove marketing kanale sa teleprodajom

- mogućnosti za promociju povećanog nivoa kvaliteta usluge, u smislu diferencijacije od konkurencije i značaja datog kupcima, umesto prodaji.

Slično grčkoj banci, implementacija i primena CRM sistema u indijskoj ICICI Bank, dovela je do smanjenja troškova, povećanja efikasnosti, bržeg odziva na potrebe tržišta i unapređenja kompetencija zaposlenih (Roy, 2008, str. 68). U ovoj banci je došlo do integrisanja funkcija: marketinga, prodaje, usluga i IT.

Na primeru Canara Bank-e, vidi se primena 
well as the alienation from customer-related experience (Karthikeyan, 2009).

Cost reduction and higher system efficiency are the main advantages offered by a quality CRM to banking institutions. Besides, it alleviates the complexity and "intricateness" occurring due to procedural steps, which customers often find ambiguous and confusing. The introduction of a CRM system in banks accelerates the response to customer inquiries, which leads to increased abilities and competencies of bank employees. Larger turnover and high ROI (Return on Investment) occur as a result of introducing a CRM software package (Stringfellow et al, 2004, pp. 45-52). The example of Greek bank illustrates that the introduction of the CRM database enables 24/7 service, with $92 \%$ success rate (Blery and Michalakopoulos, 2006, p. 123). This bank's example illustrates many other benefits of CRM implementation: cost reduction (one longterm supplier), simplification (joint platform for all banks lowering the need for integration, providing a single contact point and reducing the need for technical support) and operational improvements (improved skills of employees, alleviated problem of maintenance and support thanks to the joint platform). Integration of "voice banking" into the CRM has helped the bank get closer to its customers, offering them telephone-based banking services (stock exchange transactions, loans, etc.). Moreover, the bank did not have to hire any extra employees, given that the new call center successfully handles the increased number of incoming calls. Many activities were transferred from branch offices to the call center, which, in turn, reduced the operating costs (the cost of a call center employee is half less than the cost of a branch office employee). Branch offices were now able to focus on specialized products and customer relations. As a result of such re-organization, the bank increased the number of its clients by $5 \%$, thereby confirming the worth of its investment.

According to a study conducted in the banking sector of Sweden (Zineldin, 2005, p. 340), better location, prices, third party recommendations and advertisements are not the relevant factors when choosing a bank. From the client's perspective, the significant criteria are: accuracy and careful handling of accounts and transactions, efficient correction of errors, friendly and obliging bank employees. Therefore, the CRM attributes of high-quality products/ services, and subsequent differentiation, prove to be the most significant factors for clients. Another study, conducted in the European Bank (Blery and Michalakopoulos, 2006, p. 117) indicates that with CRM the bank was able to focus on profitable clients, through efficient segmentation towards individual behavior. Information about who purchases, what and how much they purchase, enabled the bank to employ a commercial approach based on the client, instead of on the product. This is why the bank was able to better satisfy and keep its customers. The bank's investment in the new telephone banking system reduced its servicing costs, after some operations were transferred from subsidiaries to the new call center, and at least 70 employees were redirected from other activities to sales, with a view to increasing the bank's profit. The bank's manager says: „The CRM solution gave us an opportunity to transfer over 70 employees from other operations to sales, thereby strengthening the probability of further boosting the bank's financial indicators". The CRM solution provided the bank with a higher level of effectiveness and performance, thus improving service quality and response time. Waiting time was reduced from about 20 minutes to less than 2 minutes, although the number of phone calls increased by about $40 \%$. Despite the higher volume of services (banking transactions, stock exchange transactions, loans, etc.), the conversation time decreased by $50 \%$ thanks to the new call center. Over $75 \%$ of phone calls are processed by the call center employees and the rest by the bank's IVR and voice mail. The bank is now able to manage the increasing requests much more efficiently, without the need to hire 7 more people, as would have been necessary in the old system.

Moreover, CRM has increased the bank's capital value in terms of the following:

- Coordination between the operating and marketing sectors;

- Prospects for new marketing channels including telesales;

- Possibilities for the promotion of higher service quality, in terms of a differentiation from the competition and the focus on customers instead of on sales. 
CRM sistema u cilju povećanja zadovoljstva korisnika. Zahvaljujući dobrom CRM softverskom paketu, menadžment kompanije može kvalitetno da upravlja zadovoljstvom svojih korisnika. Kao osnovne determinante zadovoljstva, u ovoj banci uzimaju: godine, pol, bračni status, nivo obrazovanja, primanja i veličina porodice. Na primeru ove banke, kroz CRM primenu, pokazano je da (Kavitha i Palanivelu, 2012, str. 102-107):

- $75 \%$ zadovoljnih korisnika dolazi iz populacije 26-50 godina;

- su $70 \%$ zadovoljnih korisnika muškarci;

- $71 \%$ zadovoljnih korisnika su u braku;

- $64 \%$ korisnika banke pripada neobrazovanom stanovništu;

- $65 \%$ korisnika banke su na donjoj granici primanja;

- $66 \%$ korisnika banke žive u porodicama koje broje preko četiri člana.

U ovoj studiji, na primeru primene CRM-a u Canara Bank, istraživanjem je dokazano da postoji statistički značajna veza između zadovoljstva korisnika i njihovog godišta, bračnog statusa i nivoa obrazovanja - dok pol, visina primanja i veličina porodice ne utiču statistički značajno na zadovoljstvo korisnika banke.

Prednosti CRM platforme su:

- smanjena potreba za upravljanjem podacima, pošto podaci nisu uzeti iz centralnog sistema;

- ažurne informacije i telefonski podaci se pojavljuju na monitorima zaposlenih, koji popravljaju učinak i veći stepen koordinacije i usluga;

- sve tačke kontakata sa kupcima su u koordinaciji (kol-centri, poslovnice i bankomati);

- iznad svega, zaposleni u kol-centru banke su sada u boljoj poziciji da usluže klijenta i dobiju njegovu povratnu informaciju kako bi poboljšali nivo usluga pruženih kupcu.

Jedna studija o očekivanju korisnika bankarskih usluga (Chopra i Arora, 2013, str. 80) upućuje na zaključak da klijenti očekuju više kada se radi o izabranim CRM praksama u bankama iz javnog i privatnog sektora. Nivo očekivanja klijenata je gotovo isti u slučaju izabranih javnih i privatnih banaka, dok je nivo percepcije (iskustva, saznanja) klijenata iz privatnih banaka mnogo veći u svim aspektima CRM-a, u poređenju sa bankama iz javnog sektora. Ova razlika u očekivanjima klijenata i percepciji klijenata ukazuje na potrebu koju bi banke trebalo da ispune ispunjavanjem očekivanja kupaca i potpunog zadovoljenja. Ova potreba je minimalna u slučaju banaka u javnom sektoru, a maksimalna u slučaju privatnih banaka. Privatne banke moraju da rade dosta efikasnije kako bi obezbedile zadovoljstvo klijenata, u poređenju sa bankama $\mathrm{u}$ javnom sektoru.

\section{CRM ključni faktori uspeha}

Jedna studija koja istražuje primenu CRM-a u bankarskim institucijama (Riyad, 2007, str. 1021-1039), pruža nove teoretske osnove za izučavanje CRM-a. CRM obezbeđuje bankama brojne operativne ključne faktore uspeha, koji mogu biti suštinski ukoliko žele da ostanu konkurentni na dinamičnom tržištu. Ova studija pruža ne samo empirijsku procenu ključnih elemenata u primeni CRM-a, već, takođe, procenjuje ključne faktore uspeha koji su izdvojeni iz sveobuhvatne relevantne literature. Ovi faktori se mogu sublimirati u tri osnovne kategorije:

1. strateške faktore

2. taktičke faktore

3. operativne faktore

Podaci iz ove studije ukazuju na tri dimenzije efektivnosti za primenu CRM-a. Ove dimenzije uključuju kvalitet odnosa (intenzivirani odnosi), kvalitet transakcije (poboljšane transakcije) i smanjenje troškova. Sve u svemu - strateški, taktički i operativni faktori objašnjavanju 56,1\% kvaliteta odnosa, 60,3\% kvaliteta transakcije i 60,9\% treće dimenzije (smanjenje troškova). Ovi podaci mogu imati velike posledice za zaposlene u marketingu, jer ukazuju da bi CRM ključni faktori uspeha trebalo da budu primenjeni u celini, pre nego u fazama, kako bi se postigao pun potencijal CRM-a. Mnogi od ključnih faktora deluju zajedno i sinergetski. Na primer, podrška top menadžmenta prema CRM-u znači da će fokus na kupca biti na vrhu njihovih prioriteta i da će se dati važnost razvoju ljudskih resursa.

Banke bi trebalo da uzmu u obzir neke faktore na strateškom nivou. Da bi se postigla strateška prednost, top menadžment bi trebalo da bude lično upoznat o potencijalima CRM-a 
Similarly as in the Greek Bank, implementation and application of the CRM system in the Indian ICICI Bank resulted in reduced costs, increased efficiency, quicker response to the market requirements, and enhanced competencies of the employees (Roy, 2008, p. 68). In this bank the following functions were integrated: marketing, sales, services and IT.

The example of Canara Bank illustrates the implementation of the CRM system for the purpose of increasing customer satisfaction. Owing to a good CRM software package, the company's management can successfully manage the satisfaction of its customers. At this bank, the basic satisfaction determinants are considered to be the following: age, gender, marital status, education level, income and family size. The bank's example, though the CRM implementation, illustrated that (Kavitha and Palanivelu, 2012, pp. 102-107):

- $75 \%$ of the satisfied clients are in the category of 26 to 50 years of age;

- $70 \%$ of the satisfied clients are male;

- $71 \%$ of the satisfied clients are married;

- $64 \%$ of the bank clients belong to the category of uneducated population;

- $65 \%$ of the bank clients are at the bottom income limit;

- $66 \%$ of the bank clients live in families with over four members.

This study, based on the example of CRM implementation in Canara Bank, empirically proves that there is a statistically relevant connection between the satisfaction of the customers and their age, marital status and education level, whereas gender, income level and family size do not significantly impact the bank's customer satisfaction.

The CRM platform advantages are:

- Reduced need for data management, given that the data are not obtained from the central system;

- Up-to-date information and phone data appear on employees' screen, improving their performance and contributing to the higher level of coordination and services;

- All customer contact points are coordinated (call centers, branch offices, ATMs);

- Above all, employees at the bank's call center are now in a better position to service the clients and get their feedback in order to upgrade the level of provided services.

A study about the expectations of bank customers (Chopra and Arora, 2013, p. 80) leads to the conclusion that customers expect more from selected CRM practices in banks in the public and private sectors. The level of clients' expectations is almost the same in selected public and private banks, whereas the level of perception (experience, information) of clients from private banks is much higher in all CRM aspects, compared with the public sector banks. This difference in clients' expectations and clients' perception indicates the need that banks should fulfill by meeting their customers' expectations and providing them complete satisfaction. This need is minimal in case of public sector banks, yet maximal in case of private banks. Private banks have to be much more efficient in order to ensure customer satisfaction, as opposed to public sector banks.

\section{Key success factors of CRM}

A study investigating the implementation of CRM in banking institutions (Riyad, 2007, pp. 1021-1039) offers a new theoretical basis for examining CRM. CRM provides numerous operational key success factors to banks, which may be deemed essential if banks wish to remain competitive in a dynamic market. Not only does this study provide an empirical assessment of key elements in the CRM implementation, but it also appraises the key success factors singled out from the comprehensive relevant literature. These factors can be summed up in the following three main categories:

1. Strategic factors;

2. Tactical factors;

3. Operational factors.

The data from this study highlight the three dimensions of CRM implementation effectiveness. These dimensions include the quality of relations (intensified relations), the quality of transactions (enhanced transactions) and cost reductions. All in all - strategic, tactical and operational factors account for $56.1 \%$ of the quality of relations, $60.3 \%$ of the quality of transactions, and $60.9 \%$ of the third dimension (i.e. cost reduction). These data may have major consequences for employees in charge of marketing, given their suggestion that the key 
i proaktivno uključen u internu primenu, kako bi upravljao njim na pravi način.

Korišćenje CRM-a u marketinške svrhe bi trebalo da bude bazirano na jasnim ciljevima. Ipak, uspešna primena CRM-a zavisi od toga koliko su jasno definisani strateški ciljevi u organizaciji. I dok su tehnološki i poslovni procesi ključni za uspeh CRM inicijativa, pojedinci na operativnom nivou saradnje sa klijentima su oni koji čine suštinu odnosa sa kupcima.

Zato CRM implementacija zahteva izmene $u$ organizacionoj kulturi banaka. CRM strategija i svaka aktivnost moraju biti usaglašene sa kompanijskom misijom, kulturom i vrednostima. Na kraju, benčmarking igra značajnu ulogu u oblikovanju strateškog pravca koji će biti dodeljen CRM paketu. Na taktičkom nivou, srednjeročno planiranje specifičnih organizacionih pitanja je veoma važno. Međutim, prihvatanje od strane zaposlenih, integracija sa drugim sistemima, izbor CRM softvera, obuka i ažuriranje znanja zaposlenih o CRM sistemima su glavni izazovi prilikom implementacije CRM sistema u bankama.

\section{Zaključak}

Banke su investirale već milijarde $u$ CRM sisteme $\mathrm{i}$ to je trend koji raste (Blery i Michalakopoulos, 2006, str. 116). Prema jednoj studiji European IT Opportunity Financial Services, CRM spada u prioritete banaka (IDC, 2002). Uspešno sprovođenje CRM rezultira odličnim kvalitetom odnosa, reflektuje poverenje kupaca u banku (pouzdanost i iskrenost) i izraženu posvećenost i lojalnost kupaca.

Jasno je da implementacijom CRM-koncepta efektivnost kompanije raste. To su prepoznale mnoge kompanije koje su razvile bonus programe za svoje verne kupce i time postigle konkurentsku prednost. Uvođenje „Miles and More" programa lojalnosti putnika i kartica za kupce vrlo je važno za British Airways: 12\% njihovih putnika leti sa ovom avio-kompanijom upravo zbog ovih programa (Kowalski, 2000, str. 338). Slični primeri u bankarskom i finansijskom sektoru pokazuju da u delu korišćenja platnih i kreditnih kartica porast lojalnosti kupaca od 5\% utiče na povećanje dobiti od 25-30\% (Reichheld i Sasser, 1990, 105-111).

Uspešna implementacija CRM koncepta omogućuje znatno smanjenje troškova. Prednosti na strani troškova su:

- niži troškovi pridobijanja kupaca (lojalni korisnici se mogu pridobiti povoljnije nego novi, postojećim klijentima je potrebno manje propagande),

- smanjenje poslovnih rizika, manji problemi dugovanja (dobri potrošači bolje plaćaju, prouzrokuju manje gubitaka),

- niži troškovi reklamacije (verni korisnici su tolerantniji prema greškama),

- smanjeni troškovi procesa (skraćeno vreme procesa i rutine koje štede vreme i/ili novac, pošto su korisnik i zaposleni stekli međusobno poverenje),

- manja fluktuacija zaposlenih (veće zadovoljstvo putem eksternog priznanja, vezivanje korisnik-zaposleni i rastuća privlačnost poslodavca),

- manji troškovi za pribavljanje i usavršavanje novih zaposlenih (lojalni zaposleni pridobijaju nove, pogodne zaposlene putem pozitivne usmene propagande) $\mathrm{i}$

- besplatna obuka zaposlenih i menadžmenta od strane angažovanih korisnika (vodi stalnom procesu poboljšanja i unapređenja poslovnih procesa).

Većina autora smatra da banke mogu značajno profitirati korišćenjem baza podataka za identifikaciju kupaca, u smislu njihove profitabilnosti, zadovoljstva, trajanja, a zatim mogu kreirati međusobnu interakciju sa ovim kupcima, uključivanjem odgovarajućeg stepena afiliacije (kontakata) (Menon i O'Connor, 2007, str. 157-168). Postoji potreba kod banaka koje rade sa građanima da unaprede svoje visoko tehnološke CRM strategije. Jedna studija (Menon i O'Connor, 2007, str. 157-168) se fokusira na kreiranje emotivne vezanosti tokom momenta interakcije između klijenata i zaposlenih u banci. Postoji mnogo interakcija u kojima ne učestvuju ljudi, već tehnologija koju klijenti koriste za rutinske i učestalije transakcije. Emotivna privrženost može, takođe, biti kreirana ili umanjena tokom tehnološki posredovane interakcije. Sadašnji koncept emotivne privrženosti koja uključuje odnos, poverenje i osećaj zajedničkih vrednosti, sa druge strane, se više bazira na intuitivnoj nego međusobnoj interakciji. Kada se emotivna privrženost stvara tokom međusobnih 
CRM success factors should be implemented concurrently, rather than in stages, in order for the full CRM potential to be achieved. Many of the key factors interact, and are in synergy. For instance, the top management's support for CRM means that customer orientation will be at the top of their priorities, and that the focus will be placed on human resources development.

Banks should be taking into account some factors at the strategic level. In order to gain strategic advantage, top management should be personally acquainted with the CRM potential and proactively engaged in its internal implementation, in order to manage it properly.

The usage of CRM for marketing purposes should be based on clear goals. A successful CRM implementation depends on how clearly the organization's strategic goals are defined. And while technological and business processes are crucial for the success of CRM initiatives, individuals at the operational level of cooperation with the clients are the ones accounting for the essence of customer relations.

This is why CRM implementation requires some changes in the organizational culture of banks. CRM strategy and all relevant activities must be in line with the company's mission, culture and values. Finally, benchmarking plays a significant role in shaping the strategic direction to be awarded to the CRM package. At the tactical level, medium-term planning of specific organizational issues is extremely important. However, acceptance by the employees, integration with other systems, selection of the CRM software, training and updating of employees' knowledge about CRM systems, remain the main challenges in the process of implementing CRM systems in banks.

\section{Conclusion}

Banks have already invested billions into the CRM systems and it is an ongoing trend (Blery and Michalakopoulos, 2006, p. 116). According to a study conducted by the European IT Opportunity Financial Services, CRM is one of the priorities of banks (IDC, 2002). Successfully implemented CRM results in excellent relationship quality, reflects the customers' confidence in the bank (its reliability and honesty), along with the prominent devotion and loyalty of customers.
Evidently enough, the implementation of the CRM concept boosts a company's effectiveness. This has been recognized by many companies which have developed bonus programs for their loyal customers, thereby achieving certain competitive advantage. The introduction of "Miles and More" passenger loyalty program and loyalty cards has been very important for British Airways: $12 \%$ of their passengers fly this company exactly because of these programs (Kowalski, 2000, p. 338). Similar examples in the banking and financial sector indicate that, when it comes to using payment and credit cards, the increase of customer loyalty by $5 \%$ causes a growth of profit by 25-30\% (Reichheld and Sasser, 1990, pp. 105-111).

Successful implementation of the CRM concept leads to considerable cost reduction. Cost benefits include the following:

- Lower costs of attracting customers (loyal customer can be attracted at more favorable costs than new ones, and the existing customers require less propaganda);

- Reduction of business risks, less debt-related problems (good customers pay better, causing smaller losses);

- Lower costs in respect of complaints (loyal customers are more tolerant towards mistakes);

- Lower processing costs (reduced processing time; routines saving time and/or money, given that the customer and the employee have acquired mutual confidence);

- Less intensive fluctuation of employees (higher satisfaction based on external recognition; connection at the customeremployee relation, and increasing attractiveness of the employer);

- Reduced costs of hiring and training new employees (loyal employees attract new, suitable employees by means of word-ofmouth propaganda); and

- Free training for employees and management by the engaged customers (leading towards the permanent improvement and upgrading of business processes).

Most authors believe that banks can profit substantially from using customer identification databases, in terms of customer profitability, satisfaction, duration, after which they can establish mutual interaction with these 
interakcija, direktan izazov za sve banke koje rade sa fizičkim licima biće da povećaju ove tačke interakcije.

Tokom 1980-tih i 1990-tih korišćenje tehnologije je bilo uključeno u strategije banaka, sa ciljem smanjivanja troškova i poboljšanja usluge. Govorniautomati, telefonskobankarstvo i Internet bankarstvo su ohrabrili klijente da prihvate do tada personalizovanu uslugu, na nepersonalan način. Ova migracija klijenata iz banaka u udaljene i vremenski neograničene provajdere, koji su zasnovani na visokim tehnologijama, bila je podržana manjim cenama transakcija, neograničenim radnim vremenom i lokacijom, što je rezultiralo smanjenjem interakcija i dodirnih kontaktnih tačaka između banke i klijenta. U svojoj želji da smanje lične kontakte u poslovnicama (i tako smanje troškove), banke nisu računale na propuštene mogućnosti za međusobne interakcije. Izazov za banke predstavljaće ponovno uključivanje i povećanje tačaka kontakta sa klijentima bez ugrožavanja faktora komfora koje se već sada kod korisnika podrazumeva. Svaka međusobna komunikacija sa klijentom bi trebalo da teži pružanju vrednosti kupcu, koje će, bez nametanja, klijentima omogućiti poboljšanje usluge banke. Povećanje ovih kontaktnih tačaka može uključivati iniciranje periodičnih pregleda bankarskih potreba klijenata i korišćenje ovih pregleda, kao mogućnost da se podstakne interakcija u cilju identifikacije načina za bolje zadovoljavanje njegovih potreba.
Ne bi trebalo zaboraviti da, za najveći deo, tehnologija može biti korišćena samo za rutinske, jednostavne bankarske usluge. U slučaju specifičnih, nerutinskih i kompleksnijih bankarskih potreba, klijenti će inicirati kontakt sa zaposlenima u banci, i njegovo prisustvo biće mogućnost za zaposlene $\mathrm{u}$ banci da kreiraju emotivnu vezanost.

Ovo je važna oblast za buduća istraživanja zato što će istinski uspešna CRM strategija biti ona koja je precizno skrojena prema potrebama klijenta za bankarskim uslugama i njegovom ponašanju. Takvo pažljivo uklapanje obezbediće efikasnije korišćenje bankarskih resursa. Uvođenje tehnologije i softvera u bankarstvo je takođe uticalo na smanjen broj zaposlenih koji su dostupni za interakciju sa klijentima. Štaviše, postoji potencijal za konflikt, jer zaposleni za rad sa fizičkim licima pokušavaju da postupaju kao prodavci i kao finansijski eksperti. Stoga je obuka zaposlenih u bankama za ove lične i tehničke veštine, kao i prodajne tehnike, od izuzetne važnosti u postavci visoko-kvalitetne usluge, što uključuje razumevanje i primenu poželjnog stila komunikacije sa klijentom u toku kontakta sa njim i prilagođavanje na adekvatan način interakcije.

Uprkos ovim izazovima, banke bi trebalo da preduzmu značajne korake u cilju osiguravanja emotivnog vezivanja, zajedno sa lojalnim ponašanjem, jer su najsnažniji brendovi oni koji imaju emotivnu privrženost korisnika. Nedavni izveštaji pokazuju da se Barclays banka (Menon

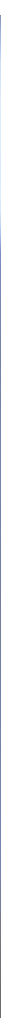


customers, including the appropriate level of affiliation (contacts) (Menon and O'Connor, 2007, pp. 157-168). There has been a need in banks dealing with retail clients to upgrade their high-tech CRM strategies. One study (Menon and O'Connor, 2007, pp. 157-168) focuses on creating emotional connection in the process of interaction between clients and bank employees. There are many interactions that do not involve people, instead relying on technology used by clients to perform routine and more frequent transactions. However, emotional connection can also be created or diminished through technologically-mediated interactions. The present concept of emotional connection implying a relationship, confidence and a sense of common values, on the other hand, is rather based on intuitive than mutual interaction. When emotional connection is created during mutual interactions, all banks working with retail clients are facing the direct challenge of highlighting these interaction points.

In the 1980s and 1990s the usage of technology was integrated into the banks' strategies, with a view to reducing costs and improving service. Voice mail, phone banking and Internet banking encouraged clients to accept until then personalized services offered in an impersonal way. This migration of clients from banks into remote and time-limited providers, based on high technology, was supported by lower transaction prices, unlimited working hours and location, having resulted in a decreased number of interactions and contact points between the bank and its customers. Wishing to reduce their personal contacts in branch offices (thereby also reducing costs), banks did not count on missed opportunities for mutual interactions. A new challenge for banks will be to re-establish and once again increase the number of contact points with the clients without jeopardizing the comfort factor which has become well understood by now. Every act of mutual communication with the client should be oriented towards providing value for customers, which would, without pressure, enable improved banking services. The mentioned increase of contact points may include the initiation of periodical reviews of the customers' banking needs and utilization of such reviews, along with the possibility to stimulate interaction in order to identify ways to better satisfy their needs.

We should bear in mind that, in the largest part, technology can only be used for routine, simple banking services. In case of specific, nonroutine, and more complex banking needs, the clients will initiate contact with bank employees, and their presence will be a chance for bank employees to create emotional connection.

This is a significant field for future research because a truly successful CRM strategy is the one precisely tailored to meet the clients' need for banking services and their banking behavior. Such careful consideration will enable a more efficient utilization of banking resources. The introduction of technology and software in banking was another reason behind the reduction of employees available for customer interaction. Moreover, there is some potential for conflict, given that retail bankers are trying to act as salesmen and financial experts. Therefore is the relevant training for bank employees in personal and technical skills, including sales techniques, of utmost importance in setting up high quality services. This also refers to comprehension and application of a desirable style of communication with the client during the contact situation, as well as the adequate adjustment of relevant interaction.

Despite these challenges, banks should undertake considerable steps to ensure emotional connection, alongside the loyal behavior of their customers, because the strongest brands are the ones that have achieved emotional devotedness of their clients. Recent reports indicate that Barclays Bank (Menon and O'Connor, 2007, pp. 157-168) decided to use a strategy rather similar to the one proposed above. They integrated several types of databases into a unique database enabling their employees to target clients through several distribution channels and communication methods, offering banking services to these clients based on their respective financial needs and modes of behavior and connection. It would be largely beneficial for other banks to follow suit.

In any case, the competitive edge depends on the transformation of data into information and knowledge, and on their accessibility to 
i O'Connor, 2007, str. 157-168) odlučila na strategiju vrlo sličnu onoj koja je predložena u ovoj strategiji. Oni integrišu nekoliko vrsta baza podataka u jedinstvenu bazu koja će omogućiti njihovim zaposlenima da ciljaju klijente kroz nekoliko kanala distribucije banke i metoda komunikacije i da im ponude bankarske usluge bazirane na njihovim finansijskim potrebama i potrebama ponašanja i vezivanja. Bilo bi od velike koristi i drugim bankama da urade isto.

U svakom slučaju, konkurentska prednost zavisi od transformacije podataka $u$ informacije i znanje, i njihove dostupnosti bankarima, koji bi zatim ovo znanje trebalo da pretvore u mogućnost za realizaciju prodaje. Na kraju, kvalitet zaposlenih je ono što će odrediti uspeh banaka u radu sa klijentima i izgradnju dugoročnih odnosa sa korisnicima.

U nadolazećim vremenima otežanog poslovanja, upotreba CRM-a, uz kvalitetnu segmentaciju korisnika i efikasan prodajni pristup, predstavljaće tačku diferencijacije uspešnih od manje uspešnih banaka.

\section{Literatura / References}

1. Berry, Leonard L. Relationship Marketing, Chicago: American Marketing Association (1983)

2. Blery, EvangeliaiMichalakopoulos, Michalis. Customer relationship management: A case study of a Greek bank. Journal of Financial Services Marketing (11) (2006)

3. Chopra, Anamica i Arora, Usha. An Analysis of the Gap Between Customers' Expectation and Perception Regarding Selected CRM Practices in Public and Private Sector Banks. IUP Journal of Bank Management (XII-4) (2013)

4. Domazet, Ivana. Unapređenje konkurentnosti preduzeća primenom CRM strategijskog koncepta. Institut Ekonomskih nauka, Ekonomska analiza (2007/3-4)

5. Ederer, Günter, Seiwert, Lothar i Küstenmacher, Werner Tiki. Der Kunde ist König: das 1x1 der Kundenorientierung: Offenbach (2000)

6. Gummesson, Evert. Making relationship marketing operational. International Journal of Service Industry Management, (5) (1994)

7. Hedley,Kimberly, John, White. Cormac, Roche i Sunny, Banerjea. IBM's Paradox of Banking 2015, IBM Institute for Business Value (2006), dostupno na https://www.304. ibm.com/easyaccess/fileserve?contentid =98335, pristupljeno: decembra 2014 .

8. Helm, Sabrina i Günter, Bernd. Kundenwert: Grundlagen - Innovative Konzepte Praktische Umsetzungen, Wiesbaden: Gabler (2003)
9. IDC. Survey - IT Adoption Patterns in the European Banking Sector: Focus on Solutions (2002)

10. Jain, Rajnish, Jain, Sangeeta i Dhar, Upinder. Curel: A Scale For Measuring Customer Relationship Management Effectiveness In Service Sector, Journal of Services Research, (2007)

11. Karthikeyan, Krishnan. A Journey in CEM, Customers Perceive Value Based on Experiences They Receive, Siliconindia (2009)

12. Kavitha, Kirar.S. i Palanivelu, P. Customer Satisfaction: CRM in Canara Bank. SCMS Journal of Indian Management, A Quarterly Journal (2012)

13. Knox, Simon., Payne, Adrian., Ryals, Lynette., Maklan, Stan. i Peppard, Joe. Customer Relationship Management: Perspectives from the Marketplace. Butterworth-Heinemann, Burlington (2003)

14. Kotler, Philip i Bliemel, Friedhelm. Marketing-Management. Analyse, Planung, Umsetzung und Steuerung. Stuttgart: Schäffer-Pöschel (1995)

15. Kowalski, Magdalena. Meilenwelt voraus, Focus (43/2000)

16. Menon, Kalyani i O'Connor, Aidan. Building customers' affective commitment towards retail banks: The role of CRM in each 'moment of truth' . Journal of Financial Services Marketing (12-2) (2007) 
bankers, who could then turn this knowledge into a possibility to strike a sale. Finally, the quality of employees is what will determine the banks' success in customer relations, and their establishment of long-term customer relationships.
In the forthcoming years of aggravated business environment, the usage of CRM, along with the quality customer segmentation and efficient sales approach, will be a point of differentiation between successful and less successful banks.
17. Österle, Hubert. Business Engineering: Prozess- und Systementwicklung. Berlin: Springer (2) (1995)

18. Raab, Gerhard. i Werner, Nicole. Customer Relationship Management, Frankfurt am Main: Verlag Recht und Wirtschaft (2009)

19. Reichheld, Frederick. i Sasser, Earl. Zero Defection: Quality Comes to Services, Harvard Business Review (1990)

20. Renart, Lluis G. i Cabré, Carles. How To Improve a CRM Strategy. IESE Business School - University of Navarra (2007)

21. Riyad, Eid. Towards a Successful CRM Implementation in Banks: An Integrated Model. The Service Industries Journal (2007)

22. Roy, Sanjit Kumar. CRM Implementation in Banks. The Icfaian Journal of Management Research (VII-7) (2008)

23. Shaw, Robert i Reed, David. Measuring and valuing customer relationships: How to develop the measures that drive profitable CRM strategies. London: Business Intelligence Ltd (1999)

24. Siddiqi, Jawed, Akhgar, Babak i Wise, Tim. A framework for the implementation of a Customer Relationship Management strategy in retail sector, Sheffield Hallam University (2008)

25. Stringfellow, Anne, Winter, Nie i Bowen, David E. CRM: Profiting from understanding customer needs, Business Horizons (2004)
26. Wahab, Samsudin, Al-Momani, Kaled i Mohd Noor, Nor Azila, The Relationship between E- Service Quality and Ease of Use On Customer Relationship Management (CRM) Performance: An Empirical Investigation In Jordan Mobile Phone Services, Journal of Internet Banking and Commerce, (15-1) (2010)

27. Winer, Russell S. Customer Relationship Management: A Framework, Research Directions, and the Future, Haas School of Business: University of California at Berkeley (2001)

28. Xavier, M.J. Fall of Traditional Brand Management: Making Way for CRM and Business Equity, Chennai: Academy for management Excellence

29. Zineldin, Mosad. Quality and customer relationship management (CRM) as competitive strategy in the Swedish banking industry, The TQM Magazine (17/4) (2005) 